\title{
Thought, Sound, Silence, Music: The Turn of the Screw from Henry James to Benjamin Britten ${ }^{1}$
}

\author{
Dídac LLORENS CUBEDO \\ UNED \\ Departamento de Filologías Extranjeras y sus Lingüísticas \\ dllorens@flog.uned.es
}

\begin{abstract}
Although Henry James was always alert to speech and dialogue, his achievement derives largely from the study of human psychology and character, and he is often perceived as a "writer of thought." The essence of Jamesian style has found an apt correlative in musical discourse and, more specifically, in the language and conventions of opera. James' The Turn of the Screw evidences an interest in the physical qualities of characters' speech and recurrently resorts to musical or performative imagery. Silence, however, is at the heart of the novella: Victorian sexual taboo, secrecry shrouding past events, the firstperson narrator's self-censorship and above all, the soundless presence of the ghostly. Benjamin Britten's opera adaptation is faithful to James' text, yet introducing fascinating elements: the definite musical character of the ghosts of Quint and Miss Jessel; their presence on stage frees them from the constraint of the Governess' narrative filter in the source text; the opera's focus on Quint, rather than the Governess, sets the homoerotic theme into relief and even suggests the ghost as the origin of the narration.
\end{abstract}

Keywords: Henry James, Benjamin Britten, The Turn of the Screw, opera adaptation, silence.

\section{INTRODUCTION: TO BEGIN AT THOUGHT}

In The Principles of Psychology (1890), William James wrote perceptively on language as a mirror image of thought and personal consciousness:

There is not a conjunction or a preposition, and hardly an adverbial phrase, syntactic form, or inflection of voice, in human speech, that does not express some shading or other of relation which we at some moment feel to exist between the larger objects of our thoughts. If we speak objectively, it is the real relations; if we speak subjectively, it is the stream of consciousness that matches each of them by an inward coloring of its own. In either case the relations are numberless, and no existing language is capable of doing justice to all their shades. (James 2007: 245)

1 The research resulting in this article relates to the project "Ideological Evolution and Transformations of the Literary Discourse in Neo-Victorian Fiction” (FFI2011-27426), which enjoyed the financial support of the Spanish Ministerio de Economía y Competitividad. 
The psychologist refers to speech as the most spontaneous manifestation of thought, but his emphasis on syntax reveals a writer's concern with sentence structure. The term "stream of consciousness" was first used in The Principles of Psychology. As we know, it would later be adopted by literary criticism, becoming associated with the work of Modernist novelists who attempted to explore those elusive "shades" of thought that James considered infinitely richer than their linguistic expression.

A pioneer of Modernist fiction, Henry James published The Turn of the Screw ${ }^{2}$ in 1898, a few years after his brother's The Principles of Psychology appeared. ${ }^{3}$ James' center of consciousness, the unnamed Governess, is presented in the frame narrative as "the youngest of several daughters of a poor country parson," "a fluttered anxious girl out of a Hampshire vicarage" (James 1966: 4), impressed by the genteel superiority of London and Essex. ${ }^{4}$ The reader, however, is led to assume that the Governess wrote her story long after the events happened, when she was no longer an inexperienced girl. This allows James to endow his character and narrator with outstanding powers of mental analysis, evidenced in her descriptions of others' reactions, meanings or intentions. We find an instance of this when, after having seen a mysterious man prowling around the house for the second time, the scared Governess hopes to be reassured by Mrs. Grose, the housekeeper:

Mrs. Grose's large face showed me, at this, for the first time, the far-away faint glimmer of a consciousness more acute: I somehow made out in it the delayed dawn of an idea I myself had not given her and that was as yet quite obscure to me. It comes back to me that I thought instantly of this as something I could get from her; and I felt it to be connected with the desire she presently showed to know more. (James 1966: 23)

The Governess often wonders what those around her know - as opposed to what they disclose - as she struggles to understand, to find out more. In The Turn of the Screw, as in other works, James seems to revel in following the trail of the main character's mental processes. His style is commonly percieved as a reflection of this penchant, materializing as intricately descriptive prose. Yet, in his essay "The Art of Fiction" (1884), James had not prioritized description. In that essay he questioned the

\footnotetext{
${ }^{2}$ I am using the Norton Critical Edition of The Turn of the Screw, which reproduces the revised New York text of 1908 (see "Works Cited”).

${ }^{3}$ Haltunnen has argued that Henry James' The Turn of the Screw is an artist's response to William James' scientific study of psychology and psychical research (487).

${ }^{4}$ The vague Brontean reminiscence evokes the lives and works of the famous Victorian authors. The Brontë sisters were the daughters of the Reverend Patrick Brontë. They lived in the village of Haworth, in Yorkshire. Charlotte and Anne (not Emily) were employed as governesses and their unsatisfactory experiences were fictionalized in novels like Jane Eyre or Agnes Grey (both published in 1847). The "governess novel” was a productive sub-genre of Victorian fiction. See note 5 below.
} 
established binary opposition between description and dialogue and argued that, in a work of fiction, they should be "melting into each other at every breath," becoming "intimately associated parts of one general effort of expression" (1994: 438).

During the 1890s, James wrote for the stage, an experience which must necessarily have confirmed for him the preponderant function and narrative potential of dialogue. Despite his enthusiasm, James' ambition to become a renowned dramatist ended in frustration and he finally understood that fiction was the best medium for his forte: the exploration of human psychology. This ability James shared with reputed actors and actresses who, as he suggested in a review, were also creators of character (Novick 2000: 10). It might be concluded, therefore, that he thought of his job as closer to that of the actor than that of the playwright.

James' failure as a playwright could be attributed to his exploratory approach to characterization, which resists dramatization. The difficulty may be partially surmounted through the aid of music: Auchard identifies "the swell of 'unheard' background music" (1986: 14) as one of the keys to the success of film adaptations of James' works. As Halliwell points out, the discourse of opera, whose "strengths ... lie in presenting intense emotional and psychological states and situations" (2000: 26), has also proved suitable in conveying the essence of Jamesian style: "it is this heightened rhetoric which translates more readily into opera" (2000: 28). Benjamin Britten's The Turn of the Screw (1954) has been the most celebrated of a good number of opera adaptations. The composer and his librettist, Myfanwy Piper, succeeded in making spectrality - represented by the characters of Peter Quint and Miss Jessel - not only visible, but also audible. In order to better understand what this entailed, I will closely examine the wealth of sounds and silences that Britten and Piper found in James' text - inspirational as well as challenging.

\section{VOICE, PERFORMANCE, SOUND AND MUSIC (JAMES' TALE)}

James' characterization often dwells on the physical qualities of speech. Several examples from The Turn of the Screw can be put forward: the external narrator approves of Douglas' elocution, comparable to the Governess' neat handwriting: "[he] had begun to read with a fine clearness that was like a rendering to the ear of the beauty of his author's hand" (James 1966: 6); when Flora denies having seen anyone from her window, the Governess notices "a long sweetness in her little drawl of the negative" (James 1966: 42); even when Miles challenges her authority, the Governess has to admit that he sounds as gentle as ever: "transcribed here the speech sounds harmless enough, particularly as uttered in the sweet, high, casual pipe with which, at all interlocutors, but above all at his eternal governess, he threw off intonations as if he were tossing roses" (James 1966: 55).

The sound of Miles's voice lulls the Governess into excusing his forwardness. Her infatuation with the boy also causes her to praise his gift for performance: 
We lived in a cloud of music and affection and success and private theatricals. The musical sense in each of the children was of the quickest, but the elder in especial had a marvellous knack of catching and repeating. The schoolroom piano broke into all gruesome fancies. (James 1966: 39)

Thus she recalls the initial idyllic days of her stay at Bly. When autumn arrives and the turn of events has obscured her happiness, she compares the house and its grounds to an empty theater: "The place, with its grey sky and withered garlands, its bared spaces and scattered dead leaves, was like a theatre after the performance - all strewn with crumpled playbills" (James 1966: 52). Later, a stage metaphor foreshadows a crisis for the Governess: "the curtain rose on the last act of my dreadful drama, and the catastrophe was precipitated" (James 1966: 55).

As the Governess' "dreadful drama” unfolds, she feels that the children deceive, manipulate or obfuscate. She expresses this conviction connecting it to the memory of sound, speech and song: by the lake, Flora's "singing" and "gabbling of nonsense" (James 1966: 35) are intended - in the narrator's retrospective perception - to distract the Governess' attention from the girl's intercourse with Miss Jessel; when Flora vanishes and the Governess anxiously senses that the child must be in the company of her ghostly friend, Miles is evasive, "breaking moreover into a happy laugh which, immediately after, as if it were a vocal accompaniment, he prolonged into incoherent, extravagant song” (James 1966: 66).

Musical metaphors in The Turn of the Screw further attest to the prominence of the imagery of performance in the tale, and of the performative arts in James' imagination. After Mrs. Grose and the children's warm welcome, not suspecting the trouble that lies ahead, the Governess could have been carried away by "the music of summer" (James 1966: 14). ${ }^{5}$ The unexpected news that Miles has been dismissed from school, however, is unsettling: "The first day had been, on the whole, as I have expressed, reassuring; but I was to see it wind up to a change of note" (James 1966: 10). Later, at a critical moment in the narration, the Governess urges Miles to explain why he left his bed and stole out of the house in the middle of the night; she could be imagined as a musician in an orchestra, under the pressure of playing a solo, fearing discordance: "I was confronted at last, as never yet, with all the risk attached even now to sounding my own horrid note" (James 1966: 46). The gap between the children's knowledge that the Governess is aware of their communication with the ghosts, on the one hand, and their pretense of ignorance and innocence, on the other, is perceived as an unsettling irony: "This situation continued a month, and with new aggravations and particular notes, the note above all, sharper and sharper, of the small ironic consciousness on the part of my pupils” (James 1966: 50). A counterargument

\footnotetext{
${ }^{5}$ This very phrase inspired Variation III in Benjamin Britten's opera The Turn of the Screw (Palmer 1990: 11).
} 
might point at the lexicalized, common nature of these "note" metaphors, but their cohesive recurrence is significant: if plot events are equated with musical notes, the narration as a whole could be thought of as a musical composition, and the characters as its performers.

The sounds considered so far are mainly related to plot and character. There are other examples of interesting - though incidental - auditory images. It is not surprising that a story like The Turn of the Screw should rely on sounds for effect: it is rooted in the Gothic tradition, where the aural often precedes the visual in triggering off uneasiness or terror. We find an example early in the narration, in its opening sequence. After Douglas has mysteriously spoken to those present about the story and its author, "quickly catching up a candlestick, he left us slightly bewildered. From our end of the great brown hall we heard his step on the stair" (James 1966: 3). Suspense will last until the manuscript arrives and is read aloud - performed before an audience of listeners, one could argue - by its owner.

Other instances of disturbing sounds are heard by the alert Governess during her first night at Bly, when the excitement prevents her from sleeping soundly: "There had been a moment when I believed I recognized, faint and far, the cry of a child; there had been another when I found myself just consciously starting as at the passage, before my door, of a light footstep” (James 1966: 8). But James' Governess immediately dismisses these Gothic sounds as "fancies," in the same way a prejudiced reader would dismiss Gothic fiction. ${ }^{6}$ She will soon learn that there is more reason to fear the silences of Bly.

\section{THE VARIOUS FACETS OF SILENCE (JAMES' TALE)}

Despite the acoustic richness of The Turn of the Screw, it can be said to revolve around a nucleus of silence. The singular quietness of the setting, for example, did not escape Virginia Woolf: "Perhaps it is the silence that first impresses us. Everything at Bly is so profoundly quiet" (qtd. James 1966: 179). Auchard has identified the various facets of silence in James' work: “absences, voids, gaps, vacancies, lacunae, and ghosts" (1986: 14). Some of these manifestations, constituting the core of James' ghost story, will be presently examined.

One of them is Victorian taboo, ruling out homosexual and paedophiliac desire, sex across social classes or women's unmarried sex. The last two "deviations" can account for the dead Governess' fate. Mrs. Grose professes not to know how Miss

\footnotetext{
${ }^{6}$ Bly reminds the Governess of the settings of Anne Radcliffe' The Mysteries of Udolpho (1794) and of Charlotte Brontë's Jane Eyre (1847): "Was there a 'secret' at Bly - a mystery of Udolpho or an insane, an unmentionable relative kept in unsuspected confinement?” (James 1966: 17). Lustig (1994: 138-146) has considered other less obvious intertextual links between these texts and The Turn of the Screw.
} 
Jessel died after she left Bly, but she does not hesitate in connecting her death with Quint's immorality. Bell wonders "whether the cause of Miss Jessel's death, which cannot be named, was not simply a pregnancy following forbidden sexuality" (1993: 105. My italics). This is only one among the many blanks that the text is interspersed with. $^{7}$

The nature of the relationship between Quint and Miss Jessel, and between them and the children, or the reason why Miles was expelled from school are the crucial enigmas on which the narration rests, and they are only indirectly and euphemistically named: "be really bad," "be an injury to the others," "something much worse," "horrors," "say things" (James 1966: 10, 11, 32, 77 \& 86). A conspiracy of silence prevents the narrator from knowing what happened before her arrival. When Mrs. Grose first tells her about Quint and Miss Jessel, the Governess feels that the housekeeper is hiding something from her: "it may be imagined whether I slept - still haunted with the shadow of something she had not told me. I myself had kept back nothing, but there was a word Mrs. Grose had kept back” (James 1966: 27). Flora and Miles are consistently silent about the interrelated enigmas mentioned above: "Never, by a slip of the tongue, have they so much as alluded to either of their old friends, any more than Miles has alluded to his expulsion" (James 1966: 48). As the Governess puts it, "the element of the unnamed and untouched became, between us, greater than any other" (James 1966: 50) - this is true of her and her charges, and of course, of her and her readers. As the narrative progresses, the reflective Governess seems to have a better understanding of this silenced reality - a "deadly view" that she does not communicate to Mrs. Grose and even refrains from putting down in writing: "But I so far succeeded in checking the expression of this view that I will throw, just here, no further light on it” (James 1966: 37).

Taboo, secrecy and self-censorship, but also the pure silence that is the ghosts's habitat and their essence. As has been indicated, Auchard includes ghosts in his analysis of James' retorics of silence: "the vacant, the void, the blank, and the dead all participate in the pressure of silence" (1986: 3). Interestingly, the apparitions invariably happen in the context of an intense and unreal silence, insightfully described. The Governess first sees Quint on the tower: "I can hear again, as I write, the intense hush in which the sounds of evening dropped. The rooks stopped cawing in the golden sky, and the friendly hour lost, for the minute, all its voice" (James 1966: 16). Similarly, Flora's deliberate silence announces the presence of Miss Jessel, standing on the other side of the lake: "I was determined by a sense that, within a minute, all sounds from her had previously dropped” (James 1966: 30) - the girl's quietness is also intended to direct the Governess' attention to the spectre of her predecessor. Quint is seen again on the stairs and, when the Governess narrates this

${ }^{7}$ Lustig has commented on the strikingly extensive use of long dashes, which leave sentences unfinished and mark the unspoken; there are about 600 in the whole text (1994: 125). 
episode, she makes the silence synonymous with her courage to confront the ghost, with her power to chase it away:

It was the dead silence of our long gaze at such close quarters that gave the whole horror, huge as it was, its only note of the unnatural. If I had met a murderer in such a place and at such an hour, we still at least would have spoken ... the silence itself which was indeed in a manner an attestation of my strength - became the element into which I saw the figure disappear. (James 1966: 41)

The collocation "dead silence" effectively conveys the conceptual association at hand. The "horror" of confronting the apparition of a dead man is intensified by the dense silence, which the Governess experiences as "unnatural": standing face to face yet unable to utter a word. The scene is replicated when the Governess finds Miss Jessel in the schoolroom; she cannot help voicing her indignation, but the ghost remains silent:

While these instants lasted, indeed, I had the extraordinary chill of a feeling that it was I who was the intruder. It was as a wild protest against it that, actually addressing her "You terrible, miserable woman!" - I heard myself break into a sound that, by the open door, rang through the long passage and the empty house. She looked at me as if she heard me. (James 1966: 59)

Probably to tease or impress Mrs. Grose, the Governess refers to this encounter as "a talk with Miss Jessel" and, curiosly, the amazed housekeeper asks "Do you mean she spoke?” (James 1966: 60). Although this is the only time the Governess sees Miss Jessel in the schoolroom, she has previously been sure of her presence and Quint's in her own territory; she has felt the unmistakable uncanny silence beneath the children's laughter, speech or music:

One of our prodigious, palpable hushes occurred - I can call them nothing else - the strange, dizzy lift or swim (I try for terms!) into a stillness, a pause of all life, that had nothing to do with the more or less noise that at the moment we might be engaged in making and that I could hear through any deepened exhilaration or quickened recitation or louder strum of the piano. Then it was that the others, the outsiders, were there. (James 1966: 53)

The last time Miss Jessel is seen by her successor, the silence is described as "flagrantly ominous" (James 1966: 70). The crisis provoked by this apparition takes Mrs. Grose and Flora away from Bly, leaving the Governess alone with Miles - and Quint. Once again, she tries to elicit from the boy the answers that will confirm her suspicions, but he seems to be in silent communication with the Master's valet:

My insistence turned him from me and kept him once more at his window in a silence during which, between us, you might have heard a pin drop. Then he was before me 
again with the air of a person for whom, outside, someone who had frankly to be reckoned with was waiting. (James 1966: 84)

The duel between the Governess and Quint will have an unexpected outcome. Miles shouts the ghost's name, and silence follows: "We were alone with the quiet day, and his little heart, dispossessed, had stopped" (James 1966: 88).

\section{FROM SILENCE TO SOUND AND SONG (BRITTEN'S OPERA)}

In Act 1, Scene 5 ("The Window") of Benjamin Britten's The Turn of the Screw, the Governess, horror-struck to hear from Mrs. Grose that Miss Jessel and Quint are dead, exclaims: "Is this sheltered place the wicked world | where things unspoken of can be?” (Piper 2010: 56). As in James' text, and as has been exemplified, Bly could be regarded as a setting symbolic of "the unspoken," but in the opera - and this is the basic difference - the ghosts that haunt the country house are not made of silence: they become audible as words and music. ${ }^{8}$

If in the novella the Governess is aware that "the others" are present because of the special quality of a sudden silence, in the opera their influence over the children is signalled in a variety of ways: the dissonance in the nursery rhyme "Tom, Tom, the Piper's Song” (sung by the children in Act 1, Scene 5, “The Window”), the sexually connoted words in Miles' Latin declension exercises (Act 1, Scene 6, “The Lesson”), the irreverence of the children's parody of a church hymn, with its untuneful musical accompaniment (Act 2, Scene 2, "The Bells") or the polytonal discords in Miles' piano playing (Act 2, Scenes 6 and 7, "The Piano" and "Flora"). Some of these effects depend on the libretto and others on the score; Palmer has technically explained the nuances of the unconventional musical devices (1990: 12-13) that serve the composer's general strategy: the inversion of "the entire 'natural' musical order of things" (1990: 10), in accordance with the unsettling presence of the ghosts at Bly.

The abstract ghostliness constantly intrudes, as moral, religious and musical propriety or naturalness are repeatedly subverted. These breaches against decorum have their origin in Quint and Miss Jessel, who - at a more perceptible level manifest themselves with the accompaniment of specific instruments. Quint is introduced by the eerie celesta, reaching the listener from an ambiguous "other world." Various exotic influences have been identified in the musical texture of the character's sound: the Balinese gamelan (an ensemble of varied percussion), or the flamenco and Arabian overtones of his melismatic singing (Palmer 1990: 8-9). Miss Jessel, on the other hand, enters the stage with the sound of a resonant gong; she is

\footnotetext{
${ }^{8}$ The opera is divided into two acts, and each one of these into eight scenes. The scenes are all preceded by an instrumental variation of an initial theme.
} 
associated with the bassoon or double bass; her soprano singing register is low and often in ascending intervals, as if "rising from the depths (possibly those of the lake)" (Teyssandier 2005: web). All these sounds and singing styles define the ghosts' musical character, which identifies or announces them - in a manner reminiscent of Wagnerian leitmotif - and correlates with the sonic vacuum that envelops them in James' text.

In the opera, the presence of Quint and Miss Jessel is distinctively heard. They sing, mostly addressing the children. In this way, the libretto dramatizes certain aspects present in the Governess' narration: the ghost's exclusive involvement with the children, the Governess' frustration at not being able to communicate with the ghosts and Mrs. Grose's failure to see the ghosts. In the last scene of Act 2 (Scene 8, "At Night”), Quint, Miles, Miss Jessel and Flora assemble. Quint presents himself in terms attractive for a child:

I am all things strange and bold,

the riderless horse

snorting, stamping on the hard sea sand,

the hero-highwayman plundering the land.

I am King Midas with gold in his hand. (Piper 2010: 61)

The images of freedom, adventure and excitement, of preciousness and beauty combine with alliteration and rhyme, making Quint's call more attractive. In James' novella, the Governess soon concludes that Miles "was under some influence operating in his small intellectual life as a tremendous incitement" (James 1966: 39). In the libretto, Quint's "influence" on Miles' "intellectual life" is concretized as sensual imagery, as allusion to the timeless world of myth: "Quint represents for Miles the opening of magic casements, a world of enchantment and glamour, of preternatural, supernatural, unattainable beauty" (Palmer 1990: 8). Soon, however, images become abstract concepts and the dark side of Quint's personality emerges:

I am the smooth world's double face,

Mercury's heels

feathered with mischief and a God's deceit.

The brittle blandishment of counterfeit.

In me secrets, and half-formed desires meet. (Piper 2010: 61)

As Deutsch points out of James' novella, Quint "holds out in one hand a promise of excitement and discovery, but in the other a warning of deception and betrayal; he represents both the desire to escape and the destruction inevitably associated with it" (2000: 77). The opera (Act 2, Scene 4: "The Bedroom”) includes the episode from the novella where Miles, alone with the Governess in his room, claims to have blown the candle out, which can be interpreted as Quint's resisting the Governess' attempt to "save" the boy. At the end of Act 1, Quint had completed his self-portrait by 
identifying with sound and movement perceived in darkness, "when the candle is out”:

I am the hidden life that stirs

when the candle is out;

upstairs and down, the footsteps barely heard.

The unknown gesture, and the soft, persistent word,

The long sighing light of the night-winged bird. (Piper 2010: 61)

Unlike Quint, Miss Jessel is portrayed as a pitiable lost soul, obsessed with revenge: her lament in the fourth scene of Act 2 ("Miss Jessel"), heard by the Governess, is poignantly sustained. In the final scene of Act 1, Miss Jessel's address, like her lover's, reaches Flora from a parallel poetic and imaginative plain, but it does not convey Quint's demonic impudence, nor the enticing images and prosodic appeal of his message. In her communication with the little girl, Miss Jessel bemoans a hopeless fate and invokes mythological figures condemned, like her, to misery, hopelessness or abandonment:

All those we have wept for together;

beauty forsaken in the beast's demesne,

the little mermaid weeping on the sill,

Gerda $^{9}$ and Psyche seeking their loves again

Pandora, with her dreadful box, as well. (Piper 2010: 62)

The characterization of Miss Jessel as a tragic, vengeful, ghastly figure is an elaboration of the libretto, and so is her direct communication with Quint. As indicated above, the ghosts sing to the children, but they also sing to each other. The opening scene of Act 2 ("Colloquy and Soliloquy") is the only one in the libretto without a correspondence in James' text. The ghosts face each other, out of time and space - "nowhere," as the stage direction fittingly indicates (Piper 2010: 64). Miss Jessel accuses Quint of having betrayed her and blames her present doom on him. Quint's elusive replies contain evocative auditory images: "the terrible sound of the wild swan's wings," "your beating heart," "the sound of my own last bell” (Piper 2010: 64). The "colloquy" ends with both characters coming together in song:

Day by day the bars we break, break the love that laps them round, cheat the careful watching eyes,

"The ceremony of innocence is drowned." (Piper 2010: 65)

\footnotetext{
${ }^{9}$ In Norse mythology, Gerda (Gerd or Gerdhr) is a beautiful giantess threatened with damnation if she refuses to marry the god Freyr. In Hans Christian Andersen's “The Snow Queen,” Gerda searches for her beloved Kai who has been bewitched by the Snow Queen.
} 
The quotation is from W. B. Yeats' apocalyptic poem "The Second Coming," composed at the end of World War I. The insertion of this line in the libretto cannot be easily explained by reference to its original context, where innocence is associated with the ideal of universal harmony, and guilt with destruction and chaos. Yet, according to Palmer, the line is "the fons et origo of Britten's musical strategy throughout The Turn of the Screw: ... this is the theme, in the widest sense, of the opera itself" (1990: 15). In its new context, this weighty and sententious line, sung in unison by two ghosts presumed guilty of having corrupted two innocent children, is particularly resonant. Britten and Piper have given possibly their most important line to two characters whom James imagined eternally silent.

\section{CONCLUSION: BRITTEN'S READING OF JAMES}

I began by focusing on James' reputation as a "writer of thought," a stylist who, paradoxically, used language to record mental activity that is necessarily silent. Although he was equally fascinated with speech and dialogue, his achievement derives largely from the study of human psychology and character. As hinted at above, the essence of his style has found an apt correlative in musical discourse, since "music affects us by perception of the senses, which then provoke emotional reactions" (Conlon 2013: 447). More specifically, the defining traits of Jamesian style (sensuality, emotion, intensity, subjectivity, sensitivity, melodrama) seem to translate particularly well into the language and conventions of opera, as several successful adaptations have confirmed (Haliwell 2000: 23).

James was a frustrated playwright, but his interest in performance is evident in The Turn of the Screw. Not only in his choice of images and metaphors (e.g. BLY IS A STAGE), but also in his mastery of ambiguity - which goes against realistic fixity, conveying a vague sense of deception - and in his choice of an unreliable narrator whose version of the events could be compared to an actress' part. The tale has a theatrical feel to it, intensified by the circumstance that a reader (Douglas) assumes the Governess' first person. Interestingly, Colm Toíbín reminds us that James' tale was heard before it was read: he dictated it to his secretary (2009: 239).

First were the sounds of The Turn of the Screw, even though the ghosts imagined by James never utter a word. In Britten's score, they have singing parts; their singing is an excluding form of communication between themselves and with the children whose corrupted innocence is projected as the opera's theme. The incarnation of the ghosts makes their interpretation as figments of the Governess' imagination, or projections of her unconscious, harder to sustain, the effect being that James' ambiguity is curtailed: "Britten is less ambiguous than James in that his ghosts clearly exist outside the governess' head: they have conversations and appear onstage even when she is absent” (Deutsch 2000: 82). In James’ original story, only the Governess 
and the readers see Quint and Miss Jessel: "The ghosts existed, it is true, only in the mind of the governess; the ghosts, more importantly, also give the reader the creeps" (Toíbín 2009: 239). In Britten's opera, there is no doubt that the children see them.

Britten is ambiguous in other ways; for instance, in dealing with homoeroticism, undoubtedly a taboo subject at the time when his operas were premiered: "His operas needed to be and not to be, to say and not to say" (Conlon 2013: 452). Britten's wish to explore this theme resulted in displacing attention from the Governess - no longer the center of consciousness - to Quint (Deutsch 2000: $79 \&$ 82), presented as an attractive character who sings some of the most beautiful passages of the opera. What is more, the Prologue - a character based on Douglas in James' text - is played by the same tenor who plays Quint, which introduces a new ambiguity: is Britten's Quint ultimately responsible for concocting a puzzling story?

Quint's role in Britten's opera and his transposition of ambiguity are indicative of the composer's selective and creative reading of a literary text that he adapted to his expressive needs while remaining faithful to its essence. The main challenge posed by James' The Turn of the Screw was the ghosts' silence, which Britten successfully turned into song and musical character. From the moment he started working on the score and supervising Piper's writing, Britten must have found inspiration in qualities of the source text that any musician could not fail to appreciate: a fascination with voice and speech, a wealth of sounds, a dramatic and musical imagination and a rich symbolism of silence.

\section{REFERENCES}

Auchard, John (1986). Silence in Henry James. The Heritage of Symbolism and Decadence. University Park: The Pennsylvania State University Press.

Baym, Nina et al. eds., (1994). The Norton Anthology of American Literature. Vol. 2. $4^{\text {th }}$ ed. New York: Norton.

Bell, Milicent (1993). Class, Sex and the Victorian Governess: James' The Turn of the Screw. In Pollack, ed., 91-119.

Bradley, John R., ed. (2000). Henry James on Stage and Screen. Houndmills: Palgrave.

Britten, Benjamin (1990). The Turn of the Screw. The Decca Record Company Limited. CD.

Conlon, James (2013). Message, Meaning and Code in the Operas of Benjamin Britten. The Hudson Review 64(3): 447-465.

Deutsch, Michelle (2000). Ceremonies of Innocence: Men, Boys and Women in The Turn of the Screw. In Bradley, ed., 72-83.

Haliwell, Michael (2000). "The Master's Voice”: Henry James and Opera. In Bradley, ed., 23-34.

Halttunen, Karen (1988). "Through the Cracked and Fragmented Self”: William James and The Turn of the Screw. American Quarterly 40(4): 472-490. 
James, Henry (1994). The Art of Fiction (1884). In Baym et al, eds., 431-445.

James, Henry (1966). The Turn of the Screw (1898). Robert Kimbrough, ed., New York: Norton.

James, William (2007). The Principles of Psychology. Vol. 1. New York: Cosimo.

Lustig, T. G. (1994). Henry James and the Ghostly. Cambridge: Cambridge UP.

Novick, Sheldon M. (2000). Henry James on Stage: "That Sole Intensity which the Theatre Can Produce.” In Bradley, ed., 1-22.

Palmer, Christopher (1990). An Inversion of the Natural Order. Liner notes. Britten, Benjamin. The Turn of the Screw. The Decca Record Company Limited. CD. 616.

Piper, Myfanwy (2010). The Turn of the Screw. Composed by Benjamin Britten. Madrid: Teatro Real.

Pollak, Vivian R. ed. (1993). New Essays on Daisy Miller and The Turn of the Screw. Cambridge: Cambridge UP.

Teyssandier, Hubert (2005). Voices of the Unseen: Benjamin Britten's Reading of The Turn of the Screw. E-rea. Révue électronique d'études sur le monde anglophone 3(2). Web (Accessed 6 December 2013).

Toíbín, Colm (2009). Pure Evil: “The Turn of the Screw.” The Henry James Review 30(3): 237-240. 